\title{
Mineralogy and Geochemistry of suspended matter collected by sedimentary traps in different parts of Lake Onego (the first data)
}

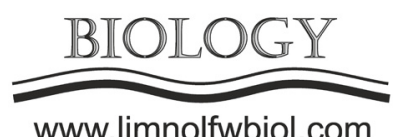

www.limnolfwbiol.com

\author{
Strakhovenko V.D. ${ }^{1 *}$, Belkina N.A. ${ }^{2}$, Potakhin M.S. ${ }^{2}$, Subetto D.A. ${ }^{3}$, Ovdina E.A. ${ }^{1}$ \\ ${ }^{1}$ V.S. Sobolev Institute of Geology and Mineralogy of the Siberian Branch of the Russian Academy of Sciences (RAS), 3 Akad. Koptyug \\ Pr., Novosibirsk, 630090 Russia \\ ${ }^{2}$ Northern Water Problems Institute of the Karelian Research Centre of the Russian Academy of Sciences, 50 Alexander Nevsky Pr., \\ Petrozavodsk, 185030 Russia \\ ${ }^{3}$ Herzen State Pedagogical University of Russia, 48 Moika Emb., Saint-Petersburg, 191186, Russia
}

\begin{abstract}
Data on the mineralogy and geochemistry of the suspended matter, the composition of its biogenic part, selected using sedimentation traps from different parts of Lake Onego, are presented. A comparative analysis of the suspended matter with the upper part of the bottom sediments of Lake was carried out. The deposited suspended matters consist of biogenic and lithogenic components. Biogenic components are represented by biogenic opal (fold valves of diatoms); lithogenic - quartz, feldspar, illite and chlorite (in which the ratio is $\mathrm{Fe} \approx \mathrm{Mg}$ ), but the suspended matter of the traps is significantly enriched with $\mathrm{Hg}$ relative to the bottom sediment.
\end{abstract}

Keywords: Lake Onego, suspended matter, sedimentary traps, bottom sediments, geochemistry, mineralogy

\section{Introduction}

The lake receives a variety of materials: solid phase of river runoff, atmospheric aerosols, coastal abrasion material, anthropogenic substance. In different parts of the lake's water area, their amounts in the total weight of suspended matter are present in different ratios. In addition, the biogenic component of the suspension is added to the water column of the lake: algae, macrophytes, dead biota material and a substance newly formed as a result of the activity of bacteria (The White, 2013). The study of sedimentation patterns in reservoirs involves the use of sedimentation traps.

Lake Onego depression is situated in the northwest part of the European Russia and is located in the contact zone of the Baltic crystalline shield (early Precambrian formations composed of $80 \%$ rocks of the tonalitetrondyemite-granodiorite (TTG) series (gray gneiss)) and the Russian Plate (the Vendian-Paleozoic platform cover) (Glushanin, Sharov, 2011). Quaternary deposits are represented by moraines of cover and mountain glaciers, glacial-lake and fluvioglacial sediments. The main purpose of the work is to characterize the mineral and geochemical composition of the suspended matter in various parts of Lake Onegj and its comparative analysis with the substance of the upper part of the bottom sediments.

\section{Material and methods}

The suspended matter entering the waters of the lake was studied by installing sedimentation traps in all areas of the Onega lake water area. A simplified version of the USL-100 sedimentation trap (ST) developed in the paleolimnology laboratory of NWPI KarRC RAS was installed. The exposure time of the ST was from 1 year. Samples of Lake Onego sediment sequence $(0$ $35 \mathrm{~cm}$ ) and suspended matter were collected aboard the scientific vessel "Ecolog" in different parts, which include: Big, Small, South Onego; Unitsky, Kondopoga, Petrozavodsk, Povenetsky, Zaonezhsky Bays. The content of major and trace elements in suspended matter and bottom sediments were determined by the methods of atomic absorption (11 probe of suspended matter and 52 samples of the oxidized zone of bottom sediments) and using ICP MS analysis (63 samples). The morphology, phase and chemical compositions of minerals in the sediments and suspended matter were determined using a Tescan MIRA 3 scanning electron microscope (SEM) (63 samples; 1214 images). Analytical work was performed at the analytical Centre of the IGM SB RAS in Novosibirsk and Paleolimnology Laboratory at the Northern Water Problems Institute of KarRC RAS.

*Corresponding author.

E-mail address: strahova@igm.nsc.ru (V.D. Strakhovenko)

(C) Author(s) 2020. This work is distributed under the Creative Commons Attribution 4.0 License. 


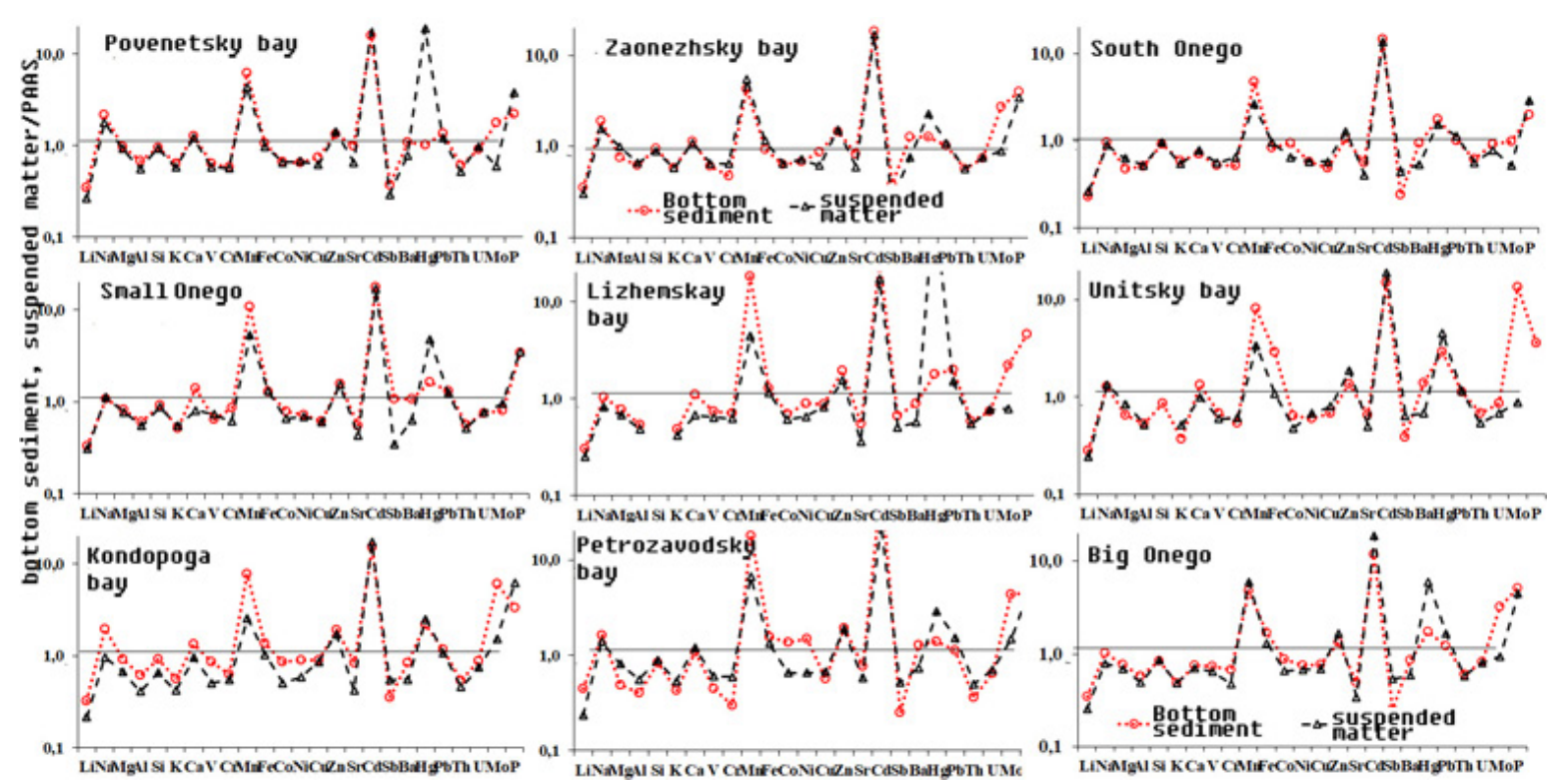

Fig.1. Distribution of element contents in in bottom sediments and suspended matters from different parts of Lake Onego columns, normalized to PAAS.

\section{Results and discussion}

Comparison of the average content of elements in bottom sediments and suspended matters from different parts of lake Onega (normalized by concentrations of Post-Archaean Australian Shale PAAS (Taylor, McLennan, 1988) did not reveal any significant differences (Fig. 1), with the exception of $\mathrm{Hg}$, which is enriched in suspended matter.

SEM of the samples showed that the suspended material is represented by diatom skeletons, detritus, pollen and a mixture of individual mineral grains, grain aggregates, flake formations of layered silicates with x-ray amorphous mass. The mineral substance is mainly composed of particles of the pelitic dimension, but part of the material of the suspended substance has the dimension of the sand-silt fraction. Among the fine suspended minerals, quartz, potassium feldspar, plagioclase (albite) and the layered minerals illite and chlorite strongly predominate. Also present: amphibole (hornblende, tremolite), epidote, kaolinite, and accessory minerals: magnetite, rutile, Apatite, monazite, zircon, etc. In addition, in the suspension of lake Onega in the Petrozavodsk Bay, fine-dispersed releases of $\mathrm{Fe}$ and $\mathrm{Mn}$ hydroxides were found.

\section{Conclusions}

The deposited suspended matters consist of biogenic and lithogenic components. Biogenic components are represented by biogenic opal (fold valves of diatoms); lithogenic - quartz, feldspar, illite and chlorite (in which the ratio is $\mathrm{Fe} \approx \mathrm{Mg}$ ), but the suspended matter of the traps is significantly enriched with $\mathrm{Hg}$ relative to the bottom sediment.

The study was supported by RFBR grant 19-05-50014

\section{References}

Glushanin L., Sharov N. 2011. The Onega Paleoproterozoic Structure (Geology, Tectonics, Deep Structure and Mineralogy); Glushanin L., Sharov N., Shtiptsov V. (Eds.). KarNTS RAN: Petrozavodsk, Russia. (In Russian)

Taylor S., McLennan S. 1988. The Continental Crust: its Composition and Evolution. An Examination of the Geochemical Record Preserved in Sedimentary Rocks. Mir: Moscow, USSR. (In Russian)

The White Sea system. 2013. Volume III. Dispersed sedimentary hydrosphere material, microbial processes and pollution. Moscow: Scientific World. 